\title{
Energy conservation by succinate decarboxylation in Veillonella parvula
}

\author{
KARIN DENGER and BeRnHARd SCHINK*
}

Lehrstuhl Mikrobiologie I, Universität Tübingen, Auf der Morgenstelle 28, 7400 Tübingen, Germany

(Received 17 December 1991; accepted 7 February 1992)

\begin{abstract}
Veillonella paroula cannot grow with succinate as sole energy source. However, succinate decarboxylation simultaneous with malate or lactate fermentation increased growth yields by $2.4-3.5 \mathrm{~g} \mathrm{(mol} \mathrm{succinate)}{ }^{-1}$. Malate was fermented stoichiometrically to acetate and propionate whereas lactate fermentation produced more acetate and considerable amounts of $\mathbf{H}_{2}$. Aspartate was utilized only in the presence of succinate as co-substrate. Methylmalonyl-CoA decarboxylase and ATP-dependent pyruvate carboxylase, but not methylmalonylCoA:pyruvate transcarboxylase, were detected in cell-free extracts of malate- or lactate-grown cells. The energetic aspects of these fermentation patterns are discussed.
\end{abstract}

\section{Introduction}

Members of the genus Veillonella are known to convert succinate to propionate and $\mathrm{CO}_{2}$ in a reaction not linked to growth (Johns, 1951; Yousten \& Delwiche, 1961). The methylmalonyl-CoA decarboxylase responsible for this decarboxylation has been isolated (Galivan \& Allen, 1968) and it was shown that the chemical energy of the decarboxylation reaction is converted into a $\mathrm{Na}^{+}$ gradient across the membrane (Hilpert \& Dimroth, 1982). Methylmalonyl-CoA decarboxylase of $V$. alcalescens (now $V$. parvula) was characterized (Hilpert \& Dimroth, 1983) and the mechanism of the $\mathrm{Na}^{+}$translocation was clarified (Hilpert \& Dimroth, 1991). The question arose whether the energy conserved in this $\mathrm{Na}^{+}$ gradient could be exploited by this bacterium.

It was the aim of this study to document and quantify the increases in growth yields of $V$. parvula by succinate decarboxylation during fermentation of other substrates, and to examine the energetic aspects and the pathways of lactate and malate degradation in this bacterium.

\section{Materials}

Sources of organisms. Veillonella parvula DSM 2007 (formerly Veillonella alcalescens ssp. alcalescens) and Propionibacterium freudenreichii ssp. shermanii DSM 20270 were obtained from the Deutsche Sammlung von Mikroorganismen, Braunschweig, FRG.

\footnotetext{
* Author for correspondence. Present address: Fakultät für Biologie; Universität Konstanz, Postfach 5560, 7750 Konstanz, Germany. Tel. 7531 882140; fax 7531882966.
}

Media and growth conditions. The mineral salts medium for cultivation was carbonate-buffered ( $30 \mathrm{mM})$, cysteine-reduced (1 $\mathrm{mM})$, and contained 7-vitamins solution (Widdel \& Pfennig, 1981), selenitetungstate solution (Tschech \& Pfennig, 1984) and the trace element solution SL 10 (Widdel et al., 1983). The $\mathrm{pH}$ was adjusted to 7·1-7.3. Yeast extract $(0 \cdot 1 \%, w / v)$ and putrescine $(20 \mu \mathrm{M})$ were added. Growth experiments were carried out at least in duplicate in $17 \mathrm{ml}$ Hungate tubes filled with $10 \mathrm{ml}$ of medium under an atmosphere of $\mathrm{N}_{2} / \mathrm{CO}_{2}$ $(90 \% / 10 \%)$. The growth temperature was $37^{\circ} \mathrm{C}$. Growth was followed by measuring optical density at $600 \mathrm{~nm}$ with a Spectronic 20 spectrophotometer.

Chemical analyses. Acetate and propionate were assayed by gas chromatography with a Carlo Erba 6000 gas chromatograph as described by Platen \& Schink (1987). $\mathrm{H}_{2}$ was determined with a thermal conductivity detector and a steel column $(2 \mathrm{~m} \times 4 \mathrm{~mm})$ packed with $60 / 80$ mesh molecular sieve ( $5 \mathrm{~A}$, Serva), detector temperature $130^{\circ} \mathrm{C}$, column temperature $50^{\circ} \mathrm{C}$, carrier gas $\mathrm{N}_{2}, 78 \mathrm{ml} \mathrm{min}^{-1}$.

AMP, ADP and ATP were analysed by HPLC according to Schnell \& Schink (1991).

Enzyme assays. Crude cell extracts were prepared from lactate-grown or malate-grown cells by sixfold passage through a French press (Aminco) at $136 \mathrm{MPa}$. Cell debris was removed by centrifugation for $10 \mathrm{~min}$ at $20000 \mathrm{~g}$. Membrane fractions were obtained by ultracentrifugation for $2 \mathrm{~h}$ at $208000 \mathrm{~g}$ (Beckman model L5.50). The pellet was resuspended in the same volume of $100 \mathrm{mM}$-Tris/ $\mathrm{HCl}$ buffer, $\mathrm{pH} \mathrm{7.5}$. All enzyme activities were measured photometrically in a Hitachi 10040 spectrophotometer at $25^{\circ} \mathrm{C}$.

Methylmalonyl-CoA : pyruvate transcarboxylase activity was quantified following NADH oxidation at $365 \mathrm{~nm}$ (modified after Stams et $a l ., 1984)$. The cuvette contained: $100 \mathrm{~mm}$ potassium phosphate buffer, pH 7.0, 0.2 mM sodium-pyruvate, 0.1 mM-NADH, 2 U malate dehydrogenase $\mathrm{ml}^{-1}$ and $0.2 \mathrm{~mm}$-methylmalonyl-CoA to initiate the reaction. $P$. freudenreichii served as control organism.

Methylmalonyl-CoA decarboxylase. The assay mixture contained $100 \mathrm{~mm}$-potassium phosphate buffer, $\mathrm{pH} 7 \cdot 0,5 \mathrm{U}$ phosphotransacetylase $\mathrm{ml}^{-1}$ and $0.1 \mathrm{~mm}$-methylmalonyl-CoA (modified after Hilpert \& Dimroth, 1983). The decrease of thioester absorbance at $232 \mathrm{~nm}$ was followed $\left(\varepsilon_{232}=4.5 \times 10^{3} \mathrm{M}^{-1} \mathrm{~cm}^{-1}\right)$. 
Pyruvate carboxylase was measured with $100 \mathrm{mM}-\mathrm{Tris} / \mathrm{HCl}$ buffer, pH 7.5, 20 mM- $\mathrm{MgCl}_{2} .6 \mathrm{H}_{2} \mathrm{O}, 1 \mathrm{~mm}$-ATP, $0.5 \mathrm{~mm}$-NADH, $1 \mathrm{U}$ malate dehydrogenase $\mathrm{ml}^{-1}, 30 \mathrm{mM}-\mathrm{KHCO}_{3}$ and $10 \mathrm{~mm}$-sodium pyruvate to start the reaction.

Malate dehydrogenase was determined by a standard method with oxaloacetate and NADH (Bergmeyer, 1974).

Malic enzyme was assayed with $40 \mathrm{mM}$-Tris/ $\mathrm{HCl}$ buffer, $\mathrm{pH} \mathrm{8.6,}$ 5 mM-L-malate and 1 mM-NAD (P).

Pyruvate : acceptor oxidoreductase was measured anaerobically with benzyl viologen as artificial electron acceptor (modified after Odom \& Peck, 1981).

Hydrogenase was assayed with methyl viologen as electron acceptor and $\mathrm{H}_{2}$ as substrate (modified after Diekert \& Thauer, 1978).

Control experiments with methylmalonyl-CoA decarboxylase and pyruvate carboxylase were carried out with crude cell extract $(0.3 \mathrm{mg}$ cells) pre-incubated for $60 \mathrm{~min}$ at room temperature with $0.1 \mathrm{mg}$ avidin or with $0.1 \mathrm{mg}$ avidin pretreated with $0.1 \mathrm{mg}$ biotin.

Protein in crude cell extracts was determined by the method of Bradford (1976) with bovine serum albumin as standard.

Chemicals. All chemicals were of reagent grade quality and obtained from Fluka, Merck, Sigma and Boehringer. Gases were obtained from Messer-Griesheim, FRG.

\section{Results}

\section{Growth experiments}

$V$. parvula grew well under strictly anaerobic conditions in a freshwater mineral medium containing $0.1 \%$ yeast extract plus $20 \mu \mathrm{M}$-putrescine. Lactate, malate or fumarate served as growth substrates. No growth could be detected with succinate, but succinate as co-substrate enhanced growth yields during growth with lactate or malate, as shown in Fig. 1.

Lactate and fumarate were converted to propionate, acetate and $\mathrm{H}_{2}$ whereas with malate no $\mathrm{H}_{2}$ was produced, and propionate and acetate were the only endproducts (Table 1). The succinate-dependent increase of growth yields was $3.5 \mathrm{~g} \mathrm{~mol}^{-1}$ and $2.4 \mathrm{~g} \mathrm{~mol}^{-1}$ with lactate- or malate-grown cells, respectively. With $10 \mathrm{~mm}$ malate or -lactate as main growth substrate, the growth yield increase by added succinate depended linearly on succinate addition (Fig. 2). the same was true for malateor lactate-dependent growth increases in the presence of a constant amount of succinate.

Only very weak growth occurred with aspartate as substrate, but succinate addition allowed growth with aspartate. Likewise, growth with succinate was possible with aspartate as co-substrate. Fig. 3 shows increasing growth yields with increasing aspartate concentrations and $10 \mathrm{~mm}$-succinate, and with increasing succinate concentrations and $10 \mathrm{~mm}$-aspartate. Aspartate also enhanced growth yields with lactate and malate (data not shown).

\section{Enzyme assays}

Contrary to classical Gram-positive propionic acid bacteria, lactate- or malate-grown cells of $V$. parvula did not contain methylmalonyl-CoA:pyruvate transcarboxylase activity. Instead, methymalonyl-CoA decarboxylase and pyruvate carboxylase activities were detected in cell extracts (Table 2). After fractionating the cell extract of lactate-grown cells by ultracentrifugation, $71 \%$ of the total methylmalonyl-CoA decarboxylase activity was found in the membrane fraction whereas pyruvate carboxylase was found entirely in the cytoplasmic fraction. Extracts pre-incubated with avidin exhibited only $20 \%$ of the methylmalonyl-CoA decarboxylase activity; biotin-saturated avidin had no inhibitory effect.

Table 1. Fermentation stoichiometries and growth yields

Experiments were carried out in $17 \mathrm{ml}$ Hungate tubes filled with $10 \mathrm{ml}$ of medium under an $\mathrm{N}_{2} / \mathrm{CO}_{2}(90 \% / 10 \%)$ gas mixture.

\begin{tabular}{|c|c|c|c|c|c|c|c|c|}
\hline Substrate(s) & $\begin{array}{c}\text { Substrate } \\
\text { degraded } \\
(\mu \mathrm{mol})\end{array}$ & $\begin{array}{l}\text { Cell dry } \\
\text { mass formed* } \\
\text { (mg) }\end{array}$ & $\begin{array}{l}\text { Substrate } \\
\text { assimilated } \dagger \\
(\mu \mathrm{mol})\end{array}$ & \multicolumn{3}{|c|}{ Products formed $(\mu \mathrm{mol})$} & $\begin{array}{l}\text { Electron } \\
\text { recovery } \\
(\%)\end{array}$ & $\begin{array}{c}\text { Molar growth } \\
\text { yield } \\
\left(\mathrm{g} \mathrm{mol}^{-1}\right)\end{array}$ \\
\hline Lactate & 100 & 0.65 & 8.9 & $53 \cdot 0$ & $37 \cdot 0$ & $16 \cdot 8$ & $98 \cdot 0$ & $6 \cdot 5$ \\
\hline $\begin{array}{r}\text { Lactate }+ \\
\text { succinate }\end{array}$ & $\begin{array}{l}100 \\
100\end{array}$ & 1.00 & $14 \cdot 0$ & $147 \cdot 0$ & $36 \cdot 0$ & $13 \cdot 7$ & $97 \cdot 6$ & $\begin{array}{c}10 \cdot 0 \\
\text { (total) }\end{array}$ \\
\hline Malate & 100 & 0.96 & $13 \cdot 2$ & $60 \cdot 0$ & $26 \cdot 0$ & - & $100 \cdot 7$ & $9 \cdot 6$ \\
\hline$\underset{\text { succinate }}{\text { Malate }}$ & $\begin{array}{l}100 \\
100\end{array}$ & $1 \cdot 20$ & $16 \cdot 4$ & $161 \cdot 0$ & $26 \cdot 2$ & - & $102 \cdot 5$ & $\begin{array}{c}12 \cdot 0 \\
\text { (total) }\end{array}$ \\
\hline Fumarate & 100 & 0.77 & $10 \cdot 5$ & $55 \cdot 0$ & $35 \cdot 0$ & $14 \cdot 2$ & $100 \cdot 4$ & $10 \cdot 5$ \\
\hline
\end{tabular}

* Cell dry mass was calculated from the optical density using the conversion factor $0.1 \mathrm{OD}_{600}=38.5 \mathrm{mg}$ dry mass $1^{-1}$.

$\dagger$ Assimilation of substrates into cell material was calculated using the formula $\left\langle\mathrm{C}_{4} \mathrm{H}_{7} \mathrm{O}_{3}\right\rangle$ for cell material, and the following assimilation equations.

17 Lactate $^{-}+8 \mathrm{H}_{2} \mathrm{O} \rightarrow 12\left\langle\mathrm{C}_{4} \mathrm{H}_{7} \mathrm{O}_{3}\right\rangle+3 \mathrm{CO}_{2}+17 \mathrm{OH}^{-}$.

17 Malate $\left.^{2-}+25 \mathrm{H}_{2} \mathrm{O} \rightarrow 12<\mathrm{C}_{4} \mathrm{H}_{7} \mathrm{O}_{3}\right\rangle+20 \mathrm{CO}_{2}+34 \mathrm{OH}^{-}$.

17 Fumarate $^{2-}+42 \mathrm{H}_{2} \mathrm{O} \rightarrow 12\left\langle\mathrm{C}_{4} \mathrm{H}_{7} \mathrm{O}_{3}\right\rangle+20 \mathrm{CO}_{2}+34 \mathrm{OH}^{-}$

Thus $13.7 \mu \mathrm{mol}$ lactate, malate or fumarate were converted into $1 \mathrm{mg}$ cell material. 

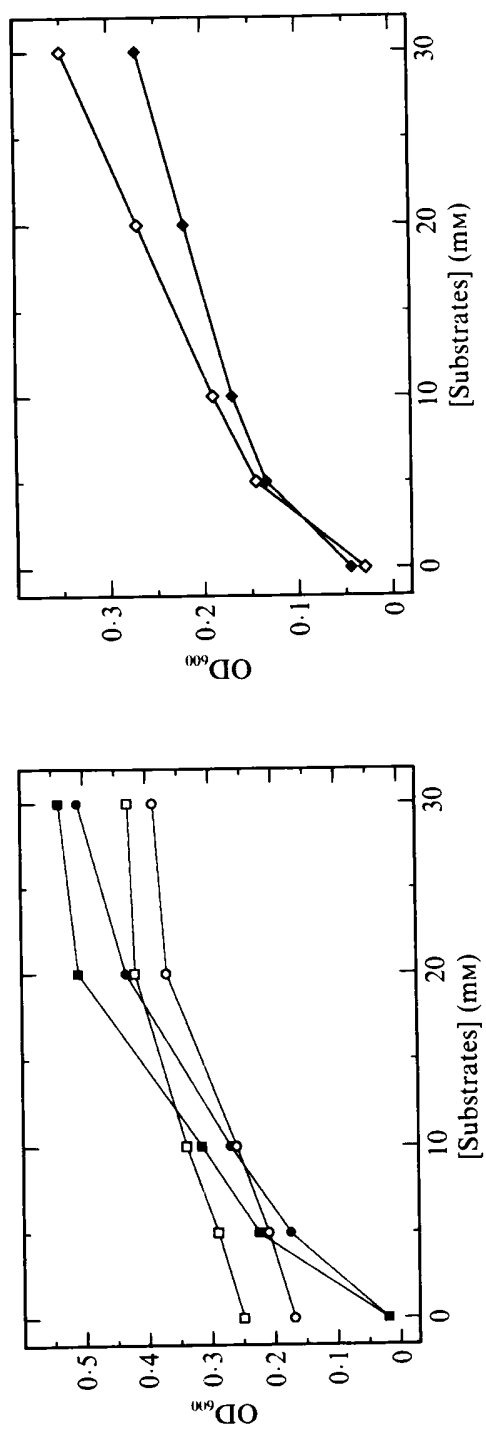

象
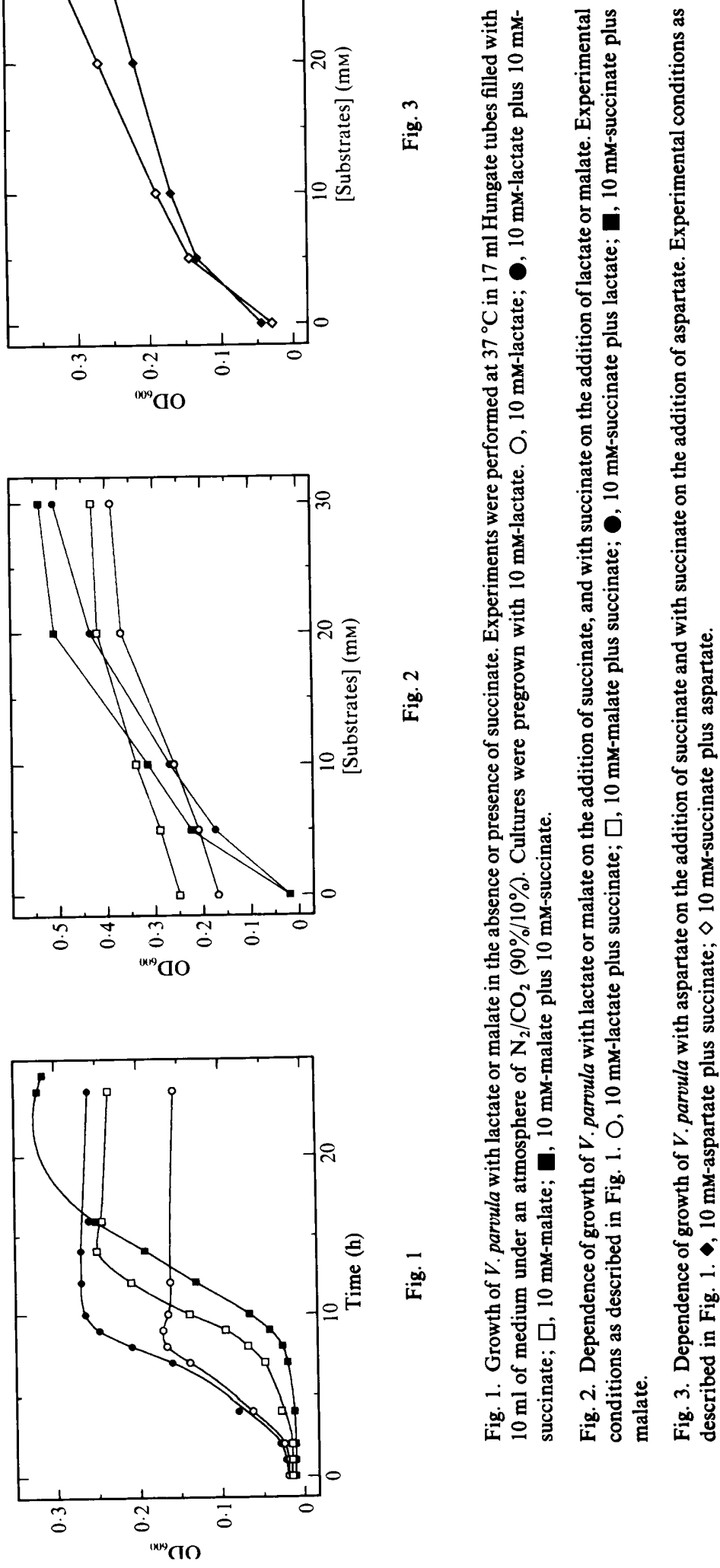

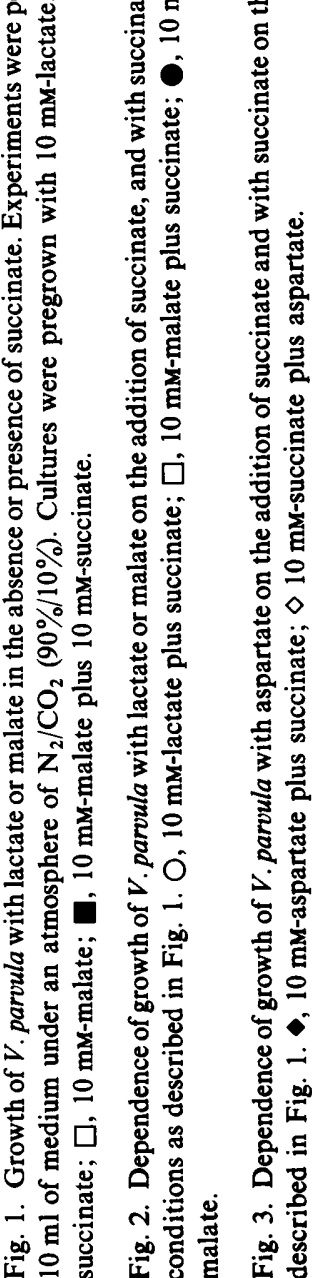


Table 2. Specific activities of enzymes detected in crude cell extracts of cells of V.parvula grown with lactate or malate

\begin{tabular}{lllc}
\hline \hline & & \multicolumn{2}{c}{ Enzyme specific activity in: } \\
\cline { 3 - 4 } \multicolumn{1}{c}{ Enzyme } & \multicolumn{1}{c}{$\begin{array}{c}\text { EC } \\
\text { number }\end{array}$} & $\begin{array}{c}\text { Lactate-grown } \\
\text { cells }\end{array}$ & $\begin{array}{c}\text { Malate-grown } \\
\text { cells }\end{array}$ \\
\hline Methylmalonyl-CoA : pyruvate & & & - \\
transcarboxylase & 2.1 .3 .1 & - & $0 \cdot 29$ \\
Methylmalonyl-CoA decarboxylase & 4.1 .1 .41 & 0.44 & - \\
Pyruvate carboxylase & 6.4 .1 .1 & $0 \cdot 08$ & 0.09 \\
Malate dehydrogenase & 1.1 .1 .37 & - & $0 \cdot 22$ \\
Malic enzyme & 1.1 .1 .38 & $0 \cdot 10$ & 0.53 \\
NAD-dependent & 1.1 .1 .40 & $0 \cdot 16$ & 6.00 \\
NADP-dependent & 1.2 .7 .1 & & $0 \cdot 28$ \\
Pyruvate:acceptor oxidoreductase & 1.18 .99 .1 & 4.20 & \\
(benzyl-viologen-dependent) & & & \\
Hydrogenase & &
\end{tabular}

A low but significant pyruvate carboxylase activity was measured in lactate- or malate-grown cells, respectively. This activity was not inhibited by avidin. ATP stimulated pyruvate carboxylase activity. ATP was converted to ADP, as analysed by HPLC. No AMP was detected in the assay mixture at the end of the reaction.

No malate dehydrogenase, but NAD- and NADPdependent malic enzyme activities were found in cell extracts of lactate or malate-grown cells. Moderate activities of benzyl-viologen-dependent pyruvate : acceptor oxidoreductase and high activities of methylviologen-dependent hydrogenase were detected in extracts of lactate- or malate-grown cells, although no $\mathrm{H}_{2}$ was produced during growth with malate.

\section{Discussion}

In the present communication, energy conservation through succinate decarboxylation by $V$. parvula is documented for the first time. In earlier studies (Hilpert \& Dimroth, 1982) it was demonstrated that methylmalonyl-CoA decarboxylase of $V$. parvula is a membranebound enzyme which couples the decarboxylation reaction with extrusion of $\mathrm{Na}^{+}$ions across the membrane. It remained unclear, however, how the $\mathrm{Na}^{+}$ gradient thus established could be exploited by the bacterium. Neither $\mathrm{Na}^{+}$-dependent nor $\mathrm{H}^{+}$-dependent ATPase was detected, no matter whether biochemical (Hilpert \& Dimroth, 1991) or immunological methods (Laubinger et al., 1990) were applied. Propionigenium modestum, on the other hand, has a $\mathrm{Na}^{+}$-ATPase and therefore can grow with succinate as sole energy source (Hilpert et al., 1984).
In the present study, succinate was shown to increase growth yields of $V$. parvula if supplied as co-substrate together with, e.g., malate or lactate. The growth yield increase was $2.4-3.5 \mathrm{~g}$ (mol succinate) $)^{-1}$, which is in the same range as growth yields of $P$. modestum grown with succinate alone (Schink \& Pfennig, 1982). This yield reflects the small free energy change of the decarboxylation reaction $\left(\Delta G_{0}^{\prime}=-25 \mathrm{~kJ} \mathrm{~mol}^{-1}\right)$, equivalent to onethird of an ATP unit (Schink, 1990). Obviously, succinate-decarboxylation-dependent $\mathrm{Na}^{+}$ion extrusion, although not supporting growth on its own, helped to save metabolic energy which was otherwise invested in, e.g., substrate uptake (Dimroth, 1987).

A specific effect of co-utilization of succinate was found with aspartate as substrate. Aspartate could be utilized only in the presence of succinate as co-substrate, indicating that the $\mathrm{Na}^{+}$ion gradient established by methylmalonyl-CoA decarboxylation may be a prerequisite of aspartate uptake in this bacterium. Involvement of a $\mathrm{Na}^{+}$ion gradient in aspartate uptake has been demonstrated recently with a Selenomonas strain, whereas malate, fumarate or lactate utilization were $\mathrm{Na}^{+}$-independent (Strobel \& Russell, 1991). Unfortunately, we could not replace succinate as a co-substrate by increased $\mathrm{Na}^{+}$ion concentrations.

Contrary to classical Propionibacterium spp., V. parvula uses pyruvate carboxylase and methylmalonyl-CoA decarboxylase rather than a transcarboxylase enzyme for formation and decarboxylation of $\mathrm{C}_{4}$-dicarboxylic acids. This pathway is energetically less efficient: 1 ATP is invested in pyruvate carboxylation, two-thirds of an ATP unit can be gained in fumarate reduction (Schink, 1990), and another one-third of an ATP unit can be conserved in methylmalonyl-CoA decarboxylation. Thus, there is no net ATP formation in the reductive 
branch of this fermentation, similar to propionate formation through the acrylyl-CoA pathway by, e.g., Clostridium propionicum or Megasphaera elsdenii (Cardon $\&$ Barker, 1947). Lactate, malate and fumarate were degraded according to the following fermentation equations (calculations of free energy changes after Thauer $e t$ al., 1977).
Formation of $\mathrm{H}_{2}$ and shift of the fermentation balance to more acetate production during lactate utilization as opposed to malate utilization is also observed with Megasphaera elsdenii during lactate fermentation (unpublished results from our laboratory), and could be a conceivable strategy to increase the ATP yield under such conditions. Experiments are in progress in our laboratory to evaluate how $\mathrm{H}_{2}$ production by the various types of propionate-forming bacteria influences the overall energetics of the fermentation process.

$$
\begin{array}{r}
10 \text { Lactate }^{-} \rightarrow 4 \text { acetate }^{-}+4 \mathrm{CO}_{2}+2 \mathrm{H}_{2}+6 \text { propionate }^{-}+2 \mathrm{H}_{2} \mathrm{O} \\
\left.\Delta G_{0}^{\prime}=-51 \cdot 8 \mathrm{~kJ} \text { (mol lactate) }\right)^{-1} \\
3 \text { Malate }^{2-}+3 \mathrm{H}^{+} \rightarrow 1 \text { acetate }^{-}+4 \mathrm{CO}_{2}+2 \text { propionate }^{-}+\mathrm{H}_{2} \mathrm{O} \\
\Delta G_{0}^{\prime}=-83.8 \mathrm{~kJ} \text { (mol malate) } \\
10 \text { Fumarate }^{2-}+10 \mathrm{H}^{+}+8 \mathrm{H}_{2} \mathrm{O} \rightarrow 4 \text { acetate }^{-}+14 \mathrm{CO}_{2}+2 \mathrm{H}_{2}+6 \text { propionate } \\
\Delta G_{0}^{\prime}=-82.7 \mathrm{~kJ}\left(\text { mol fumarate) }^{-1}\right.
\end{array}
$$

\section{References}

BergmeYer, H. U. (1974). Methoden der enzymatischen Analyse, 3rd edn. pp. 649-653. Weinheim, FRG: Verlag Chemie.

BRADFORD, M. (1976). A rapid and sensitive method for the quantification of microgram quantities of protein utilizing the principle of protein-dye binding. Analytical Biochemistry 72, 248254.

Cardon, B. P. \& Barker, H. A. (1947). Amino acid fermentation by Clostridium propionicum and Diplococcus glycinophilus. Archives of Biochemistry and Biophysics 12, 165-180.

DIEKERT, G. \& THAUER, R. K. (1978). Carbon monoxide oxidation by Clostridium thermoaceticum and Clostridium formicoaceticum. Journal of Bacteriology 136, 597-606.

DimRoTh, P. (1987). Sodium ion transport decarboxylases and other aspects of sodium ion cycling in bacteria. Microbiological Reviews 51, 320-340.

Galivan, J. H. \& Allen, H. G. (1968). Methylmalonyl coenzyme A decarboxylase. Journal of Biological Chemistry 243, 1253-1261.

HILPERT, W. \& DIMROTH, P. (1982). Conversion of the chemical energy of methylmalonyl-CoA decarboxylation into a $\mathrm{Na}^{+}$gradient. Nature, London 296, 584-585.

HILPERT, W. \& DIMROTH, P. (1983). Purification and characterization of a new sodium-transport decarboxylase. European Journal of Biochemistry 132, 579-587.

HILPERT, W. \& DIMROTH, P. (1991). On the mechanism of sodium ion translocation by methylmalonyl-CoA decarboxylase from Veillonella alcalescens. European Journal of Biochemistry 195, 79-86.

Hilpert, W., Schink, B. \& DimRoth, P. (1984). Life by a new decarboxylation-dependent energy conservation mechanism with $\mathrm{Na}^{+}$as coupling ion. EMBO Journal 3, 1665-1670.

JoHNS, A. T. (1951). The mechanism of propionic acid formation by Veillonella gazogenes. Journal of General Microbiology 5, 326-336.

LaUbinger, W., DeCkers-Hebestreit, G., Altendorf, K. \& DIMROTH, P. (1990). A hybrid adenosinetriphosphatase composed of $F_{1}$ of Escherichia coli and $F_{0}$ of Propionigenium modestum is a functional sodium ion pump. Biochemistry 29, 5458-5463.

ODOM, J. M. \& PECK, H. D. (1981). Localization of dehydrogenases, reductases and electron transfer components in the sulfate-reducing bacterium Desulfovibrio gigas. Journal of Bacteriology 147, 161-169.

Platen, H. \& SCHINK, B. (1987). Methanogenic degradation of acetone by an enrichment culture. Archives of Microbiology 149, 136-141.

SchinK, B. (1990). Conservation of small amounts of energy in fermenting bacteria. In Biotechnology, pp. 63-89. Edited by R. K. Finn \& P. Präve. Munich: Hanser.

SCHINK, B. \& PrEnNIG, N. (1982). Propionigenium modestum gen. nov., sp. nov., a new strictly anaerobic nonsporting bacterium growing on succinate. Archives of Microbiology 133, 209-216.

SCHNELL, S. \& SCHINK, B. (1991). Anaerobic aniline degradation via reductive deamination of 4-aminobenzoyl-CoA in Desulfobacterium anilini. Archives of Microbiology 155, 183-190.

Stams, A. J. M., Kremer, D. R., Nicolay, K., Weenk, G. H. \& HANSEN, T. A. (1984). Pathway of propionate formation in Desulfobulbus propionicus. Archives of Microbiology 139, 167-173.

STROBEL, H. J. \& RUSSELL, J. B. (1991). Role of sodium in the growth of a ruminal selenomonad. Applied and Environmental Microbiology 57, 1663-1668.

Thauer, R. K., Jungermann, K. \& Decker, K. (1977). Energy conservation of chemotrophic anaerobic bacteria. Bacteriological Reviews 41, 100-180.

Tschech, A. \& Pfennig, N. (1984). Growth yield increase linked to caffeate reduction in Acetobacterium woodii. Archives of Microbiology 137, 163-167.

WIDDEL, F. \& PFENNIG, N. (1981). Studies on dissimilatory sulfatereducing bacteria that decompose fatty acids. I. Isolation of new sulfate reducing bacteria enriched with acetate from saline environments. Description of Desulfobacter postgatei gen. nov., sp. nov. Archives of Microbiology 129, 395-400.

WIDDEL, F., KoHRING, G. W. \& MAYER, F. (1983). Studies on dissimilatory sulfate-reducing bacteria that decompose fatty acids. III. Characterization of the filamentous gliding Desulfonema limicola gen. nov., sp. nov., and Desulfonema magnum sp. nov. Archives of Microbiology 134, 286-294.

Yousten, A. A. \& Delwiche, E. A. (1961). Biotin and vitamin B $_{12}$ coenzymes in succinate decarboxylation by Propionibacterium pentosaceum and Veillonella alcalescens. Bacteriological Proceedings 61, 175. 